\title{
PROTEIN SYNTHESIS IN NEURONAL PERIKARYA ISOLATED FROM CEREBRAL CORTEX OF THE IMMA- TURE RAT ${ }^{1}$
}

\author{
H. H. KoHL and O. Z. SelLiNGER ${ }^{2}$ \\ Mental Health Research Institute, The University of Michigan Medical Centre, Ann Arbor, \\ Michigan 48104.
}

(Received 9 August 1971. Accepted 8 October 1971)

\begin{abstract}
Homogenates of neuronal perikarya isolated from the cerebral cortex of the 8-day-old rat were incubated with $\left[{ }^{3} \mathrm{H}\right]$ leucine, and the characteristics of the protein synthetic process were studied. Incorporation of leucine into protein was linear up to $90 \mathrm{~min}$, proceeded optimally at $\mathrm{pH} 7 \cdot 6$ and was stimulated by $\mathrm{K}^{+}$and $\mathrm{NH}_{4}{ }^{+}$, unaffected by $\mathrm{Li}^{+}$ and inhibited by $\mathrm{Na}^{+}$. Puromycin, cycloheximide, RNAse, sulphhydryl blocking agents and phospholipase $A$ exerted a pronounced inhibition, whereas chloramphenicol and phospholipase $C$ had no effect. About 42 per cent of the total radioactive protein formed in the optimally fortified in vitro system was recovered in non-sedimentable form. Incorporation into the subcellular fractions of the neuronal perikarya increased steadily with increasing time of incubation. The microsomal fraction acquired the highest specific radioactivity (d.p.m./mg of protein), followed by the mitochondrial and the nuclear + cell debris fractions. The high-speed soluble fraction exhibited the lowest specific radioactivity.

Although the addition of L-methionine to a suitably fortified incubation medium inhibited neuronal protein synthesis by about 80 per cent, the addition of D-methionine, $a$-methyl-DLmethionine or L-tryptophan was relatively ineffective by comparison.
\end{abstract}

MANY DIFFERENT preparations have been used to study cerebral protein synthesis in vitro: whole tissue homogenates (JoHnson and LUTTGES, 1966; PETERSON and MCKEAN, 1969), slices (Folbergrová, 1966; OJA, 1967; VAHVElainen and OJA, 1969), cell-free systems (JOHNSON, 1968) consisting of microsomes (MURTHY and RAPPOPORT, 1965; Lim and AdAMS, 1967), ribosomes (CAMPBELl, MAHLER, Moore and Tewari, 1966; Zomzely, Roberts, Gruber and Brown, 1968; Sellinger and Ohlsson, 1969; Lerner and Johnson, 1970; Zomzely, Roberts, PeACHe and Brown, 1971 ; Sellinger, Ohlsson, Frankel, Azcurra and Petiet, 1971b), mitochondrial fractions (HALdAR, 1970; GoldberG, 1971; MAHLER, JoNes and MOORE, 1971), nuclei (BURDMAN and JouRNEY, 1969; LøVTRUP-REIN, 1970; FLEISCHER-LAMBROPOULOS and ReINSCH, 1971) and nerve-ending preparations (APPEL, Autilio, FestofF and ESCUETA, 1969; GoLDBERG, 1971), with the last probably contaminated by membranes of glial derivation (Cotman, Herschman and Flansburgh, 1970). Although findings stemming from these and many more investigations have uncovered features characteristic of cerebral protein synthesis, they have not made it possible to distinguish unequivocally between, and to evaluate separately, the respective contributions of the neurons and the glial cells to the overall synthetic performance of this highly complex tissue.

\footnotetext{
${ }^{1}$ This work was supported by grant No. NS-06294 from the United States Public Health Service.

${ }^{2}$ All correspondence to this author.

Abbreviations used: BSA, bovine serum albumin; PPO, 2,5-diphenyloxazole; dimethyl POPOP, 1,4-bis[2-(4-methyl-5-phenyloxazolyl)]-benzene; PVP, polyvinyl pyrrolidone.
} 
Recently, however, high-yield methods for the bulk-separation of neuronal perikarya and glial cells have become available (see reviews by JoHNSTON and RooTs, 1970; and BLOMSTRAND, 1971), and thus efforts to study neuronal and glial protein synthesis separately have been initiated in several laboratories (BLOMSTRAND and Hamberger, 1969, 1970; Takahashi, Hsu and Honma, 1970; Hemminki, Huttunen and JARNEFELT, 1970; BURDMAN, 1970; BLOMSTRAND, HAMBERGER and YANAGIHARA, 1971; Tiplady and Rose, 1971; Sellinger, Azcurra, Johnson, Ohlsson and LODIN, 1971a; JOHNSON and SELLINGER, 1971). In a previous communication from our laboratory, we compared neuronal and glial protein synthesis in vivo (JoHNSON and SELLINGER, 1971) and found that both cell types rapidly incorporate intracerebrally-administered $\left[{ }^{14} \mathrm{C}\right]$ phenylalanine into protein. In the present report, we have examined the capacity of the isolated neuronal perikarya (SELLINGER et al., 1971a) to carry out protein synthesis in vitro, and we have described some of the parameters which influence this process. A preliminary account of some of the results has appeared (KoHL and SELLINGER, 1971).

\section{EXPERIMENTAL PROCEDURES}

Animals and materials. Male 8-day-old Sprague-Dawley rats were, used since the yield of neuronal perikarya is optimal at this age (JoHnson and SELlinger, 1971 ; SELlinger, MEDzIHRADSKy, SANTIAGO and NANDHASRI, 1971c) and protein synthetic activity, as measured in experiments in vivo, is intense (JOHNSON and SELLINGER, 1971 ; SELLINGER et al., $1971 \mathrm{la}$ ). L- $\left[4,5-{ }^{3} \mathrm{H}\right]$ Leucine with a specific radioactivity of $5 \mathrm{Ci} / \mathrm{mmol}$ was obtained from New England Nuclear Corp. (Boston, Mass.). Bovine serum albumin (BSA, fraction V) was obtained from Pentex Biochemicals (Kankakee, Ill.). Polyvinylpyrrolidone (PVP; Plasdone C, average mol. wt. 40,000) was purchased from GAF Corporation (Calvert City, Kentucky). Ficoll was obtained from Pharmacia (Uppsala, Sweden). Sucrose (special enzyme grade) was purchased from Mann Research Laboratories (New York, N.Y.). PPO and dimethyl POPOP were obtained from Packard Instruments (Downers Grove, 1ll.). Hyamine hydroxide was purchased from Research Products Int. Corp. (Elk Grove, Ill.). Whatman glassfibre filters (GF/C) were purchased from Curtin Scientific Co. (St. Louis, Mo.). Nylon bolting cloth was obtained from Tobler, Ernst and Traber (Elmsford, N.Y.). Phospholipase A (EC 3.1.1.4) (Crotalus terr. terr.), bovine pancreatic RNase (EC 2.7.7.16) (5x cryst.), K- or Na-phosphocreatine, phosphocreatine kinase (EC 2.7.3.2), 2-phosphoenol-pyruvic acid-tricyclohexylammonium salt, pyruvate kinase (EC 2.7.1.40), pronase ( $B$ grade), and dithiothreitol were purchased from the California Biochemical Corp. (Los Angeles, Calif.). GTP was obtained from the Pierce Chemical Co. (Rockford, Ill.); trisor Na-ATP and chloramphenicol (chloromycetin) were from the Sigma Chemical Co. (St. Louis, Mo.). Cycloheximide (Acti-Dione) and puromycin dihydrochloride were purchased from Nutritional Biochemicals Co. (Cleveland, Ohio) and phospholipase C (lecithinase C) (EC 3.1.4.3) was from the Worthington Biochemical Corp. (Freehold, New Jersey).

Preparation of incubation media. All solutions and incubation media were made in glass-distilled water which had been sterilized by autoclaving shortly before use. Reagent solutions and the incubation media were checked for bacterial contamination by plating samples of each on blood-agar slants and by inoculation into a liquid thioglycolate medium followed by overnight culturing at $37^{\circ} \mathrm{C}$. No bacterial colonies were noted. In addition, controls were run which contained $\left[{ }^{3} \mathrm{H}\right]$ leucine, the complete incubation medium and, in lieu of the neuronal homogenate, an equal volume of $0.25 \mathrm{M}$-sucrose used to wash out the bottom of a centrifuge tube (for the Spinco SW-25 rotor) which had been carried through the procedure for the isolation of neuronal perikarya (SELLINGER et al., 1971a), but in which $20 \mathrm{~m}$ l of the polyvinyl-pyrrolidone-bovine serum albumin-calcium chloride solution (instead of $20 \mathrm{ml}$ of a sieved cortical suspension) was layered on top of the two-step sucrose gradient. The incorporation of $\left[{ }^{3} \mathrm{H}\right]$ leucine in this incubated control (intended to assess the extent of bacterial protein synthesis) was no greater than that in the zero-time acid-inactivated controls incubated in the presence of tissue.

Incubation and counting of radioactivity. Rats were killed by decapitation and the neuronal perikarya were isolated from the cerebral cortices, according to the method of SELLINGER et al. (1971a). Suspensions of the isolated neuronal perikarya were homogenized in $0.25 \mathrm{M}$-sucrose by 10 up-anddown strokes at $1300 \mathrm{rev} / \mathrm{min}$ in a Potter-Elvehjem glass-teflon homogenizer (clearance $0.0043 \mathrm{in}$.). Portions of the neuronal homogenate were incubated at $37^{\circ} \mathrm{C}$ in the following media (final concentrations given):

Medium A: 0.001 mM-L-[4,5- $\left.{ }^{3} \mathrm{H}\right]$ leucine, $(5 \mu \mathrm{Ci}) ; 50 \mathrm{mm-tris,} \mathrm{(pH} \mathrm{7 \cdot 6);} 250 \mathrm{mm-sucrose.}$ 


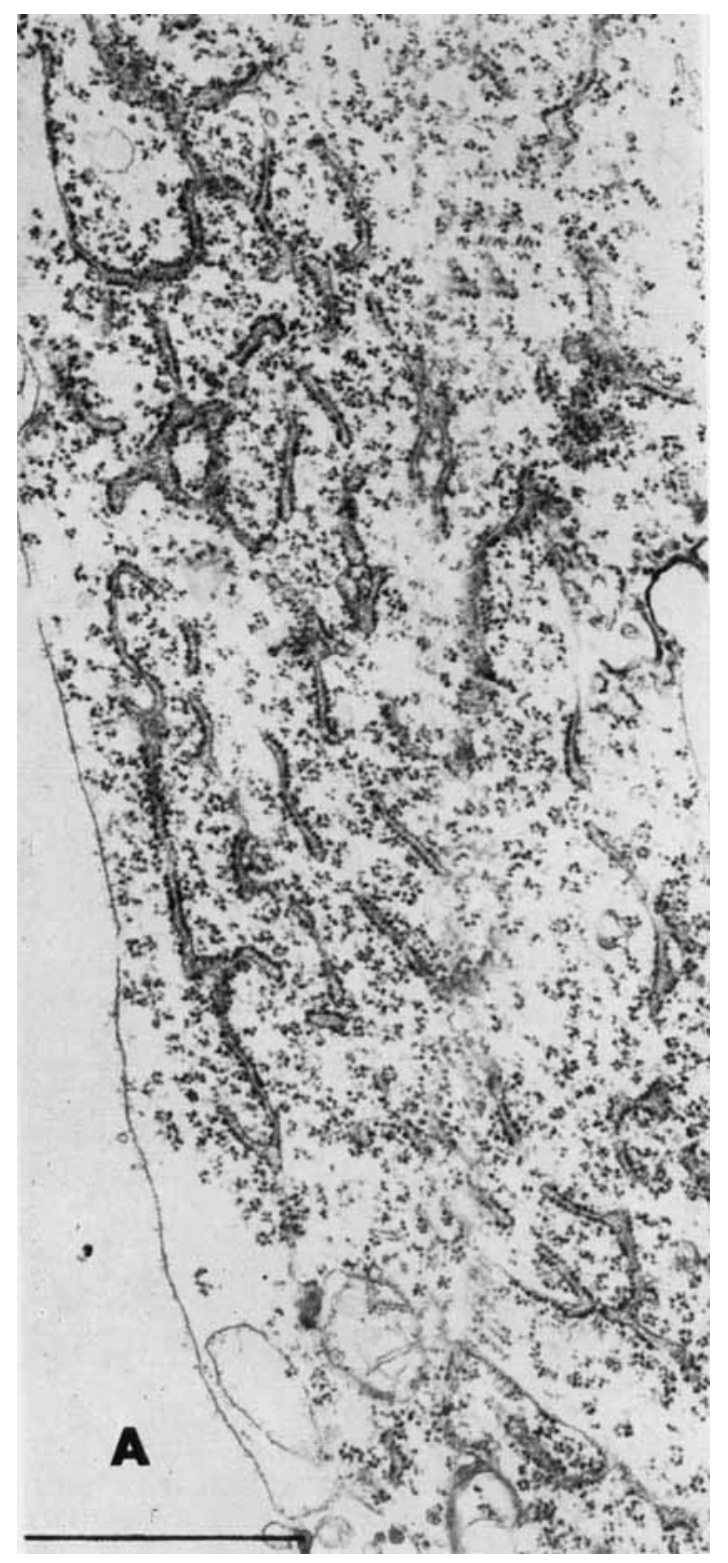

FIG. 1(A) 


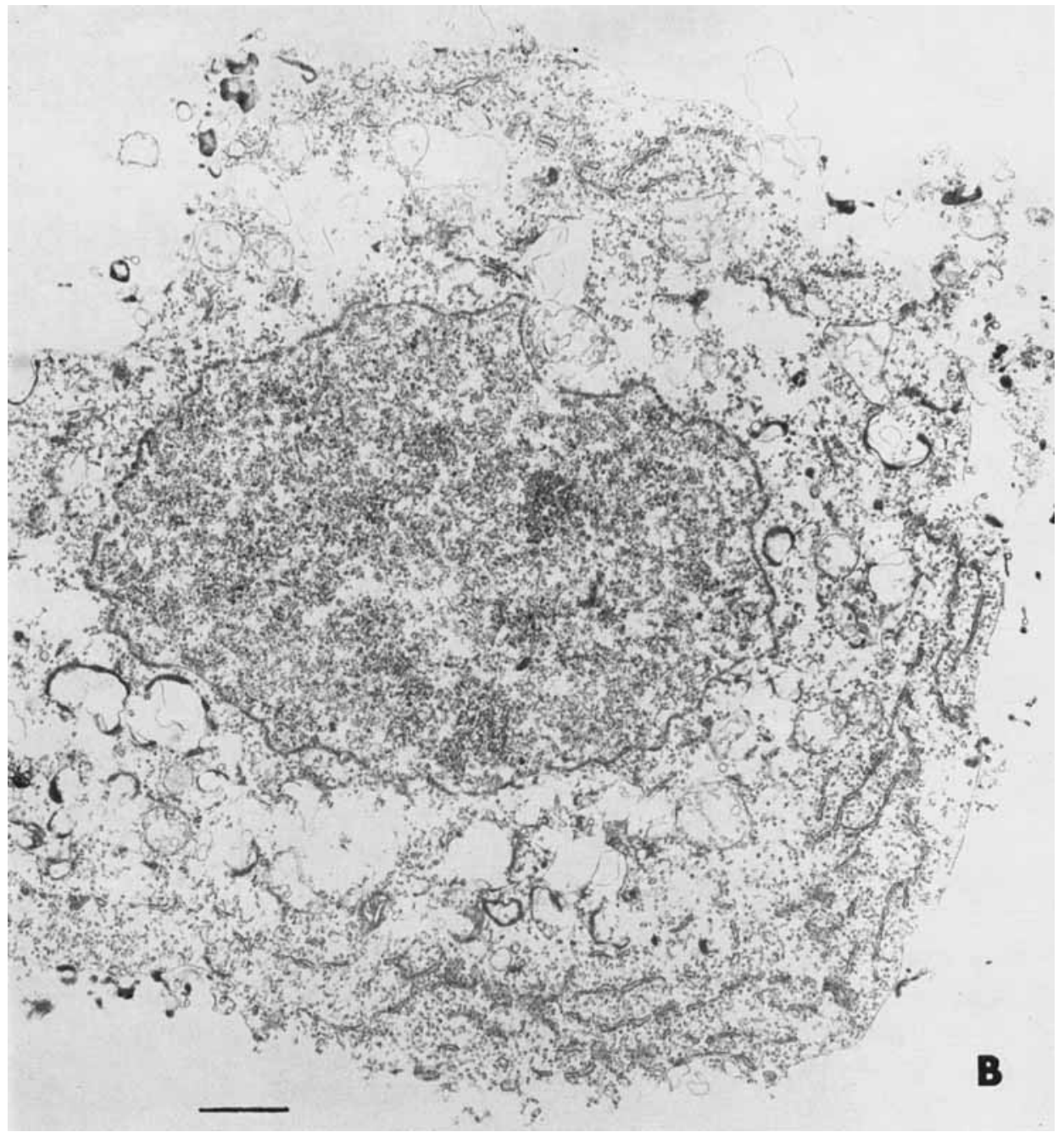

FIG. 1(B)

Fig. 1.-A Detail of a neuronal perikaryon isolated from the cerebral cortex of an 8-day-old rat by the method of SELLINGER et al. (1971a). Note the intact portion of the cellular plasma membrane and the abundant free and membrane-bound ribosomes. Negative $\times 10,200$; print $\times 40,800$. The calibration bar denotes $1 \mathrm{~nm}$.

B. Typical appearance of the immature neuronal perikaryon. Note the irregular contour of the nuclear membrane. Mitochondrial profiles are not as well preserved as after isolation in a medium containing $10 \mathrm{~mm}$-tris buffer and $25 \mathrm{~mm}-\mathrm{KCl}$ (SELLINGER, Santiago and Petiet, unpublished observations). Negative $\times 4,000$; print $\times 16,000$. The calibration bar denotes $1 \mathrm{~nm}$. 
Medium B: $0.001 \mathrm{mM}-\mathrm{L}-\left[4,5-^{3} \mathrm{H}\right]$ leucine, (5 $\left.\mu \mathrm{Ci}\right) ; 50 \mathrm{~mm}$-tris, (pH 7.6); $5 \mathrm{~mm}$-Na-phosphate, (pH 7.6); $5 \mathrm{mm-KCl} ; 120 \mathrm{~mm}-\mathrm{NaCl} ; 2.5 \mathrm{~mm}-\mathrm{MgCl}_{2} ; 20 \mathrm{~mm}$-glucose; 2.5 mM-Na-ATP; 250 mMsucrose. (After Blomstrand and HAMBERGER, 1970).

Medium $\mathrm{B}_{1}: 0.001 \mathrm{~mm}-\mathrm{L}-\left[4,5-{ }^{3} \mathrm{H}\right]$ leucine, $(5 \mu \mathrm{Ci}) ; 50 \mathrm{~mm}$-tris, (pH 7.6); $20 \mathrm{~mm}$-Mg-acetate; $75 \mathrm{mM}-\mathrm{KCl} ; 2.5 \mathrm{~mm}$-tris-ATP; $250 \mathrm{~mm}$-sucrose.

Medium C: $0.001 \mathrm{~mm}-\mathrm{L}-\left[4,5-{ }^{3} \mathrm{H}\right]$ leucine, $(5 \mu \mathrm{Ci}) ; 50 \mathrm{mM}$-tris, $(\mathrm{pH} 7.6) ; 10 \mathrm{~mm}$-Mg-acetate; $75 \mathrm{~mm}-$ $\mathrm{KCl} ; 2.5 \mathrm{~mm}$-tris- or Na-ATP; $0.1 \mathrm{~mm}-\mathrm{GTP} ; 20 \mathrm{~mm}$-phosphocreatine; creatine phosphokinase, $100 \mu \mathrm{g} ; 0.5 \mathrm{~mm}$-dithiothreitol; $250 \mathrm{mM}$-sucrose.

After the addition of $\left[{ }^{3} \mathrm{H}\right]$ leucine to the prefilled and chilled tubes, they were incubated at $37^{\circ} \mathrm{C}$. Following incubation, protein was precipitated by the addition of $5 \mathrm{ml}$ of $10 \%(\mathrm{w} / \mathrm{v})$ TCA containing non-radioactive $\mathrm{L}$-leucine $(2 \mathrm{mg} / \mathrm{ml})$. Samples were left in an ice bath for $30 \mathrm{~min}$ and were then heated at $90^{\circ} \mathrm{C}$ for $30 \mathrm{~min}$ to hydrolyse the radioactive amino-acyl transfer RNA. They were subsequently cooled on ice for another $30 \mathrm{~min}$ and the precipitated material was mechanically suspended using a vortex mixer and then manually homogenized before filtration through the GF/C filters. The filters were washed five times with $1 \mathrm{M}-\mathrm{HCl}$, twice with $95 \%(\mathrm{v} / \mathrm{v})$ ethanol and once with ether. Additional washes using ethanol-ether $(1: 1, \mathrm{v} / \mathrm{v})$ were unnecessary.

The dried filters were placed in scintillation vials; hyamine $(0.5 \mathrm{ml})$ was added, and the sealed vials were left at room temperature overnight. Then $10 \mathrm{ml}$ of scintillation fluid, containing $4 \mathrm{~g}$ of PPO and $0.1 \mathrm{~g}$ of dimethyl POPOP per litre of toluene, were added and the radioactivity was counted in a Nuclear Chicago spectrometer (model Unilux II), at a counting efficiency of 35-40 per cent. Quenching corrections were carried out by the channels-ratio method and were checked from time-to-time with an internal standard of $\left[{ }^{3} \mathrm{H}\right]$ toluene. The counts/min were converted to d.p.m.

In separate experiments in which the incorporation of $\left[{ }^{3} \mathrm{H}\right]$ leucine into soluble and particulate protein was determined, incubations were terminated by the addition of $10 \mathrm{ml}$ of ice-cold $0.25 \mathrm{M}$ sucrose containing non-radioactive L-leucine $(2 \mathrm{mg} / \mathrm{ml})$. The tubes were centrifuged in the Spinco 50 rotor at $150,000 \mathrm{~g}$ for $120 \mathrm{~min}$. This procedure produced a supernatant (soluble) and a pellet (particulate) fraction.

Subcellular distribution of the radioactive protein. In these experiments, the incorporation was terminated by the addition of $7.5 \mathrm{ml}$ of ice-cold $0.25 \mathrm{M}$-sucrose containing non-radioactive L-leucine $(2 \mathrm{mg} / \mathrm{ml})$. Samples were centrifuged at $3000 \mathrm{~g}$ for 15 min to yield a pellet designated as the crude fraction of nuclei and cell debris and a supernatant fraction which was centrifuged at $20,000 \mathrm{~g}$ for $20 \mathrm{~min}$. The resulting pellet was designated as the crude mitochondrial fraction. The post-mitochondrial supernatant fluid was centrifuged at $270,000 \mathrm{~g}$ for $90 \mathrm{~min}$ to yield the microsomal fraction (pellet) and the cell sap fraction (supernatant fluid). All $g$-values quoted refer to $r_{a v}$.

Protein was determined by the method of LowRY, ROSEBRoUGH, FARR and RANDALL (1951), and DNA was measured by the procedure of CROFT and LUBAN (1965).

Electron microscopy. All procedures used were as previously described (JoHNSON and SELLINGER, 1971) for the electron microscopy of neuronal perikarya from 18-day-old rat brain.

\section{RESULTS}

Electron microscopy. Previously unpublished electron micrographs of neuronal perikarya from cerebral cortex of 8-day-old rats, after isolation by the technique of SELLINGER et al. (1971a), are illustrated in Fig. 1. Free and membrane-bound ribosomes are evident, as well as prolonged portions of the plasma membrane. Approximately 42 per cent of the DNA contained in the nylon-sieved suspension of the cerebral cortex (first step of the procedure of SeLLINGER et al., 1971a) was recovered in the pellet of the neuronal perikarya. Since this pellet consists virtually exclusively of neuronal perikarya (JoHNSON and SelLINGER, 1971), recovery of DNA refers to a cellular yield of 42 per cent.

Composition of the incubation medium and the formation of radioactive protein. The quantitative effects of fortifying the basal medium A (see Methods) with additional components were evaluated (Table 1). A 400 per cent increase above the level of basal incorporation of $\left[{ }^{3} \mathrm{H}\right]$ leucine into neuronal protein (Medium A, Table 1) was achieved by adding the components 2 through 7 (Table 1). Further additions of glucose or inorganic phosphate did not augment the incorporation significantly. The energy-generating system of phosphocreatine and phosphocreatine kinase could be 
replaced by phosphoenolpyruvate and pyruvic kinase with no change in the extent of incorporation. The responses of the basal system (Table 1) to the addition of the individual components were qualitatively similar to those described by JoHnson (1968) and ZOMZELY, ROBERTS and RAPAPORT (1964), inasmuch as all of them required the addition of an ATP-generating system for maximal incorporation.

TABLE 1.--EFFECT OF THE ADDITION OF INDIVIDUAL COMPONENTS ON THE INCORPORATION OF L-[4,5-3 H] LEUCINE INTO NEURONAL PROTEIN in vitro

\begin{tabular}{lcc}
\hline \multicolumn{1}{c}{ Incubation medium } & \multicolumn{2}{c}{ Specific radioactivity } \\
& $\begin{array}{c}\text { (d.p.m. per } \\
\text { mg of } \\
\text { protein) }\end{array}$ & $\begin{array}{c}\text { Increase } \\
\text { (Per cent) }\end{array}$ \\
\hline (1) Basal (Medium A)* & 2133 & 0 \\
(2) 1 + $\mathrm{Mg}^{2+}, 10 \mathrm{~mm}$ & 2478 & 17 \\
(3) 2 + KCl, 75 mM. & 2767 & 30 \\
(4) 2 + ATP, 2.5 mM. & 3218 & 52 \\
(5) 4 + GTP, 0.1 mM. & 4178 & 97 \\
(6) 5 + Phosphocreatine, 10 mM, & & 336 \\
(7) 6 + Dithiothreitol, 0.5 mM & 7130 & $36.1 \mathrm{mg}$. \\
& & \\
\hline
\end{tabular}

* See 'Methods' for full details.

Neuronal perikarya were isolated, homogenized, incubated and processed for determination of incorporation of the radioactivity into protein as described under Methods. Incubations were for $30 \mathrm{~min}$ at $37^{\circ} \mathrm{C}$, with addition of $5 \mu \mathrm{Ci}$ of $\left[{ }^{3} \mathrm{H}\right]$ leucine per tube. Reactions were terminated by the addition of $10 \%(w / v)$ TCA, and all tubes were subjected to heating at $90^{\circ} \mathrm{C}$ for $30 \mathrm{~min}$. Each value represents the mean of triplicate determinations in two separate experiments. Deviations from the mean value in each experiment did not exceed 10 per cent.

Inhibitors. The effects of some inhibitors of protein synthesis are summarized in Table 2. In these experiments, the fortified medium $C$ (see Methods) was used. The extent of inhibition by cycloheximide varied as a function of the concentration of $\mathrm{Mg}^{2+}$ : from 45 per cent at $10 \mathrm{mM}-\mathrm{Mg}^{2+}$ to zero at $20 \mathrm{~mm}-\mathrm{Mg}^{2+}$. A similar $\mathrm{Mg}^{2+}$. dependent inhibition of protein synthesis by cycloheximide was recently observed by OBRIG, CULP, MCKeEHAN and HARDESTY (1971), who used a preparation of reticulocyte ribosomes. Addition of pancreatic RNase inhibited the incorporation of $\left[{ }^{3} \mathrm{H}\right]-$ leucine by 65 per cent (Table 2), whereas addition of phospholipase $A$ reduced protein synthesis by 47 per cent. Phospholipase $C$ was without effect. These latter observations suggested that the fatty acids liberated by phospholipase $A$ were inhibitory, whereas the phosphorylcholine produced by the action of phospholipase $C$ was not. We showed that the inhibitory effect of phospholipase $A$ was not attributable to a contaminating protease by adding the phospholipase after $30 \mathrm{~min}$ of incubation and noting no degradation of the newly-formed radioactive protein after an additional period of incubation. Previously ACS, NeIDLE and SCHNEIDERMAN (1962) have shown that fatty acids inhibit the incorporation of amino acids by brain ribosomal prepara- 
TABLE 2.-INHIBITION OF NEURONAL PROTEIN SYNTHESIS

\begin{tabular}{|c|c|c|c|}
\hline Expt. no. & Inhibitor & $\begin{array}{l}{\left[{ }^{3} \mathrm{H}\right] \text { Protein }} \\
\text { formed } \\
\text { (d.p.m. per mg } \\
\text { of protein) }\end{array}$ & $\begin{array}{l}\text { Inhibition } \\
\text { (Per cent) }\end{array}$ \\
\hline 1 & $\begin{array}{l}\text { None* } \\
\text { Puromycin, } 500 \mu \mathrm{g} / \mathrm{ml} \\
\text { Cycloheximide, } 500 \mu \mathrm{g} / \mathrm{ml} \\
\text { Chloramphenicol, } 500 \mu \mathrm{g} / \mathrm{ml} \\
\text { Pancreatic RNase, } 500 \mu \mathrm{g} / \mathrm{ml} \\
\text { Phospholipase A, } 5 \mathrm{IU} / \mathrm{ml} \\
\text { Phospholipase C, } 1 \mathrm{IU} / \mathrm{ml}\end{array}$ & $\begin{array}{r}13,950 \\
4185 \\
7670 \\
13,980 \\
4880 \\
7395 \\
13,960\end{array}$ & $\begin{array}{r}0 \\
70 \\
45 \\
0 \\
65 \\
47 \\
0\end{array}$ \\
\hline 2 & $\begin{array}{l}\text { None } \dagger \\
\text { Pronase, } 500 \mu \mathrm{g} / \mathrm{ml} \\
N \text {-ethyl maleimide, } 1 \times 10^{-3} \mathrm{M}\end{array}$ & $\begin{array}{r}4710 \\
250 \\
1075\end{array}$ & $\begin{array}{r}0 \\
95 \\
77\end{array}$ \\
\hline
\end{tabular}

* Medium C (see Methods) was used.

$\uparrow$ Medium B (see Methods) was used.

For details, see text. Incubations were for $60 \mathrm{~min}$ at $37^{\circ} \mathrm{C}$. Abbreviation: IU, international units.

tions. A requirement for reduced sulphhydryl groups was suggested by the stimulation produced when dithiothreitol was added (Table 1) and, conversely, by the inhibitory action of $N$-ethyl-maleimide (Table 2). In separate experiments, the incorporation of $\left[{ }^{3} \mathrm{H}\right]$ leucine in medium $\mathbf{B}_{1}$ was almost totally blocked by the addition of either p-chloromercuribenzoate or iodoacetamide $\left(1 \times 10^{-3} \mathrm{M}\right)$.

Kinetics, $p H$ and salt concentration. In medium C (see Methods), the incorporation of $\left[{ }^{3} \mathrm{H}\right]$ leucine into neuronal protein proceeded at linear rates for at least $90 \mathrm{~min}$ (Fig. 2). Linear kinetics with respect to homogenate protein were also seen.

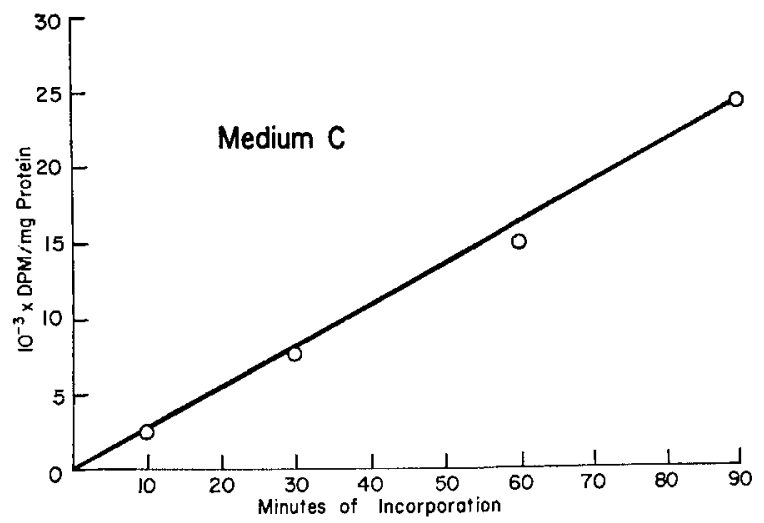

FIG. 2.-Incorporation of $\left[{ }^{3} \mathrm{H}\right]$ leucine into proteins of neuronal homogenates as a function of time of incubation at $37^{\circ} \mathrm{C}$. Each value represents the mean of triplicate determinations obtained in a typical experiment. The individual values were within 10 per cent of the mean value. For composition of medium $\mathrm{C}$, see Methods. 
Synthesis of proteins by the neuronal homogenate was optimal in the $\mathrm{pH}$ range of 7.4-7.8 (Fig. 3), and a pH of 7.6 was chosen for incubations in medium $\mathrm{C}$. The optimal concentration of $\mathrm{Mg}^{2+}$ was about $10 \mathrm{mM}$; lowering $\left[\mathrm{Mg}^{2+}\right]$ to $5 \mathrm{~mm}$ decreased incorporation by 56 per cent, whereas increasing $\left[\mathrm{Mg}^{2+}\right]$ to $20 \mathrm{mM}$ decreased synthesis by 14 per cent. Protein synthesis in medium $C$ was stimulated by the addition of $\mathrm{K}^{+}$, whereas $\mathrm{Na}^{+}$in the presence or absence of $\mathrm{K}^{+}$was inhibitory (Fig. 4). Addition of $\mathrm{NH}_{4}{ }^{+}$stimulated the incorporation of $\left[{ }^{3} \mathrm{H}\right]$ leucine and $\mathrm{NH}_{4}{ }^{+}$could substitute for $\mathrm{K}^{+}$, whereas $\mathrm{Li}^{+}$was ineffective and could not replace $\mathrm{K}^{+}$. Cerebral protein synthetic systems are more sensitive to ionic modulations than similar systems from other

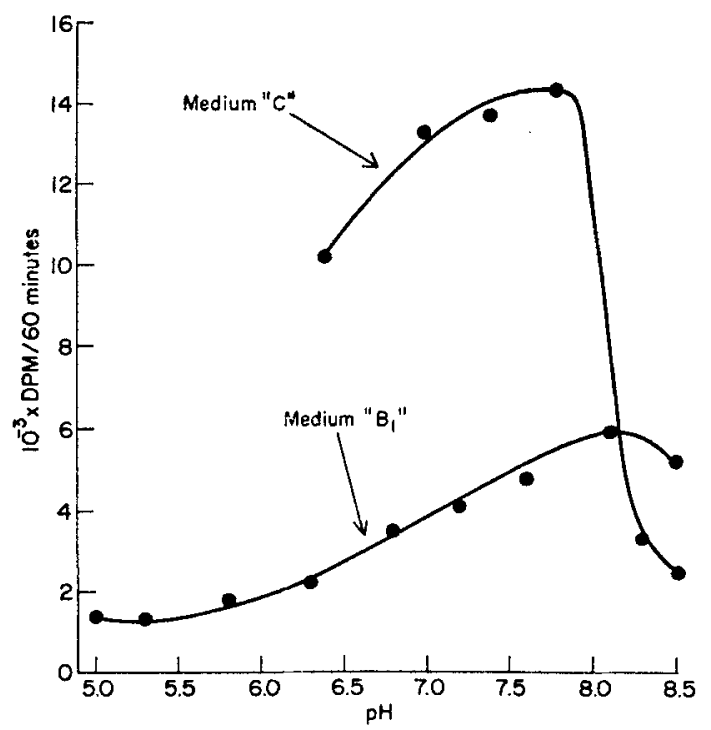

FIG. 3.-Effect of pH on incorporation of $\left[{ }^{3} \mathrm{H}\right]$ leucine into neuronal protein. Homogenates of neuronal perikarya were incubated in either medium $B_{1}$ or $C$. (see Methods). Medium $B_{1}$, containing $50 \mathrm{~mm}-2[N$-morpholino]ethane sulphonic acid, was adjusted to the requisite $\mathrm{pH}$ by addition of solid tris(hydroxymethyl) amino methane base. Medium $\mathrm{C}$ was adjusted to the desired $\mathrm{pH}$ by addition of either solid tris- $\mathrm{HCl}$ or tris-base. The $\mathrm{pH}$ values are those of the media after incubation.

organs, and $\mathrm{K}^{+}$reportedly stimulates the process (ZOMZELY et al., 1964; STENZEL, Aronson and Rubin, 1966; Goodwin, Shafritz and Weissbach, 1969). K+ ${ }^{+}$, as well as $\mathrm{Na}^{+}$, also stimulated the incorporation of leucine into rabbit neuronal protein following the incubation of brain slices and subsequent isolation of a neuron-enriched fraction (BLOMSTRAND and HAMBERGER, 1970).

Addition of methionine and tryptophan. Our data (Fig. 5) indicate that the incorporation of $\left[{ }^{3} \mathrm{H}\right]$ leucine into protein was markedly inhibited by the addition of L-methionine. The degree of inhibition varied as a direct function of the concentration of methionine added. At $10 \mathrm{mM}$, L-methionine exerted a 50 per cent inhibition in the unfortified system $B_{1}$ (see Methods) and an 80 per cent inhibition in the fortified system C (see Methods). D-Methionine appeared relatively inert by comparison, as did $a$-methyl-DL-methionine and L-tryptophan. Since a homogenate was used, these 


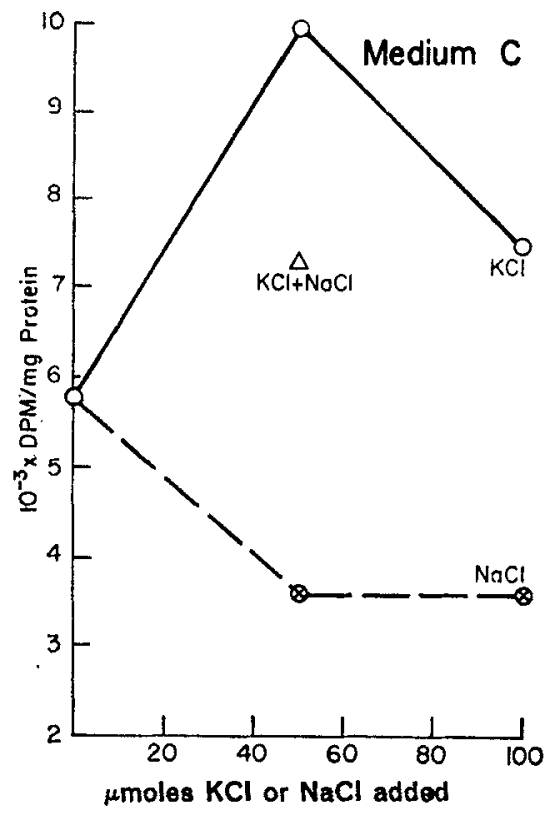

FIG. 4.-Effects of the addition of $\mathrm{Na}^{+}$or $\mathrm{K}^{+}$on the incorporation of $\left[{ }^{3} \mathrm{H}\right]$ leucine into neuronal proteins. Medium $\mathrm{C}$ was used, containing $2.5 \mathrm{~mm}$-di-Na-ATP and $10 \mathrm{mM}$ di-Na-phosphocreatine. Total $\mathrm{Na}^{+}$was thus $25 \mu \mathrm{mol}$ greater than that shown on the abscissa. Incubation time was $20 \mathrm{~min}$ at $37^{\circ} \mathrm{C}$. Each point represents the mean of triplicate determination in two separate experiments. $\Delta$ refers to $50 \mu \mathrm{mol}$ each of $\mathrm{K}^{+}$and $\mathrm{Na}^{+}$added to the medium.

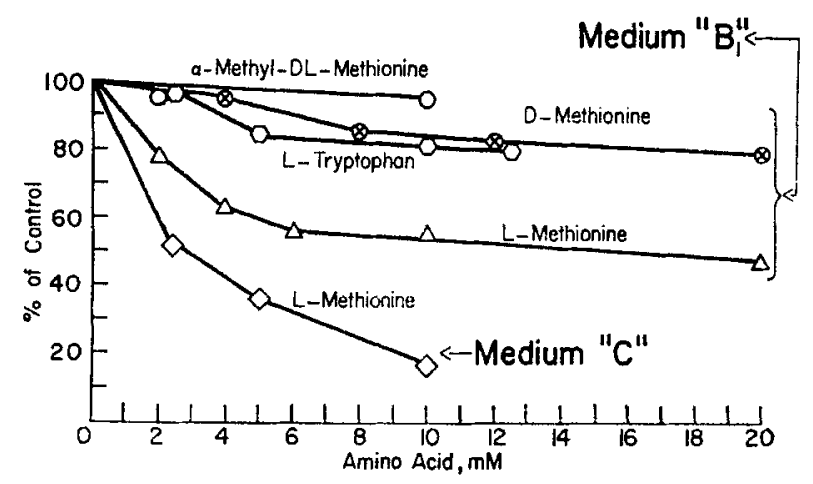

FiG. 5.-Effects of the addition of amino acids on the incorporation of $\left.{ }^{3} \mathrm{H}\right]$ leucine into neuronal proteins. Samples were incubated for $20 \mathrm{~min}$ at $37^{\circ} \mathrm{C}$. Values are the means of triplicate determinations. Deviations from the mean were within 10 per cent of the stated value. See Methods for composition of media.

inhibitory responses cannot be ascribed to interference by the added amino acid with the transport of leucine across the cell plasma membrane.

Incorporation into subcellular fractions. The incorporation of $\left[{ }^{3} \mathrm{H}\right] \mathrm{leucine}$ took place into both soluble and particulate proteins and increased in both fractions with increasing time of incubation (Table 3 ). A substantial portion of the total radioactivity 
TABle 3.-The formation OF SOluble NeURONAL PROTEIN

\begin{tabular}{|c|c|c|c|c|c|c|}
\hline \multirow{3}{*}{$\begin{array}{l}\text { Incubation } \\
\qquad(\min )\end{array}$} & \multicolumn{6}{|c|}{ Radioactive protein } \\
\hline & \multicolumn{2}{|c|}{ Soluble } & \multicolumn{2}{|c|}{ Particulate } & \multicolumn{2}{|c|}{ Percent soluble } \\
\hline & (d.p.m.) & $\begin{array}{l}\text { (d.p.m. per mg } \\
\text { of protein) }\end{array}$ & (d.p.m.) & $\begin{array}{l}\text { (d.p.m. per mg } \\
\text { of protein) }\end{array}$ & (d.p.m.) & $\begin{array}{l}\text { (d.p.m. per mg } \\
\text { of protein) } \dagger\end{array}$ \\
\hline 5 & 365 & 354 & 446 & 2483 & 45 & 14 \\
\hline 15 & 727 & 703 & 1337 & 7469 & 35 & $9 \cdot 4$ \\
\hline 30 & - & - & 2073 & 12,564 & - & - \\
\hline 60 & 2237 & 1621 & 2780 & 15,379 & 45 & $13 \cdot 8$ \\
\hline
\end{tabular}

* Soluble + particulate $=100$ per cent.

$\dagger$ (Soluble/particulate) $\times 100$.

Incorporations were carried out by incubating the homogenized neuronal perikarya at $37^{\circ} \mathrm{C}$ in medium C (see Methods). Reactions were suppressed by adding $10 \mathrm{ml}$ of ice-cold, $0.25 \mathrm{M}$-sucrose containing $2 \mathrm{mg}$ of non-radioactive L-leucine per ml. The tubes were centrifuged in the Spinco 50 rotor at $150,000 \mathrm{~g}$ for $120 \mathrm{~min}$ to yield a particulate and soluble fraction. Values are the means of duplicate determinations in two separate experiments. The deviations from the mean values did not exceed 10 per cent for the particulate fraction and 20 per cent for the soluble fraction.

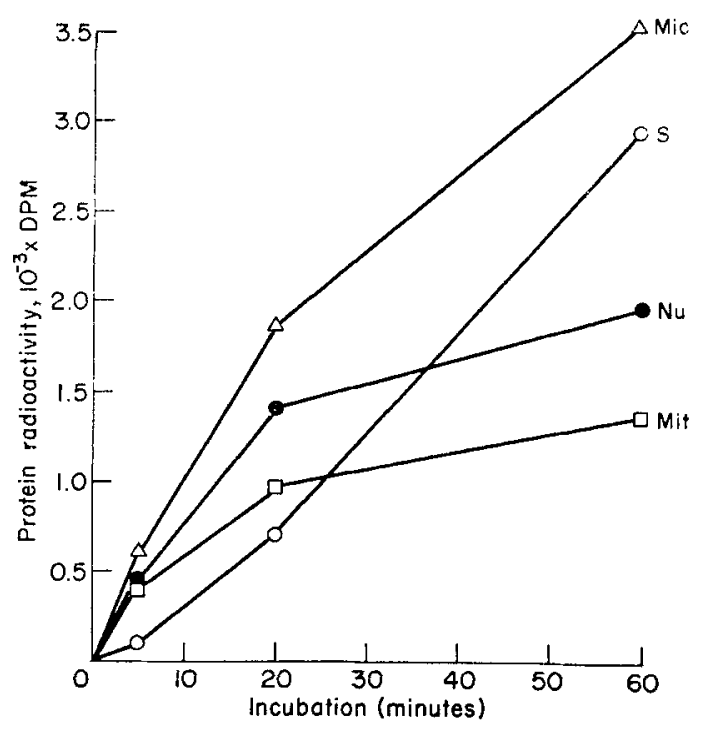

FIG. 6.-Incorporation of $\left[{ }^{3} \mathrm{H}\right]$ leucine into the proteins of subcellular fractions of neuronal perikarya as a function of time of incubation at $37^{\circ} \mathrm{C}$. To terminate an experiment, incorporation was suppressed by the addition of $7.5 \mathrm{ml}$ of ice-cold, 0.25 $\mathrm{M}$-sucrose containing $2 \mathrm{mg}$ of non-radioactive leucine per ml. Samples were centrifuged at $3000 \mathrm{~g}$ for $15 \mathrm{~min}$ to yield a fraction $(\mathrm{Nu})$ designated as nuclear + cell debris. The post-nuclear supernatant fluid was centrifuged at $20,000 \mathrm{~g}$ for 20 min to yield a crude mitochondrial pellet (Mit). The post-mitochondrial supernatant fluid was centrifuged at $270,000 \mathrm{~g}$ for $90 \mathrm{~min}$ to obtain a microsomal pellet (Mic) and a soluble cell sap fraction (S). Values represent the means of triplicate determinations. Nu: nuclear fraction; Mit: crude mitochondrial fraction; Mic: microsomal fraction; S: soluble cell sap fraction. 
(averaging about 42 per cent) appeared as soluble (non-sedimentable) protein. However, the specific radioactivity (d.p.m. per $\mathrm{mg}$ of protein) of this soluble protein averaged only about 11 per cent of that of the particulate protein. Appreciable labelling in vitro of neuronal soluble protein was recently also reported by BLOMSTRAND. et al. (1971), following incubation with $\left[{ }^{3} \mathrm{H}\right]$ leucine of a neuron-enriched preparation isolated from adult rabbit cerebral cortex. There was an increasing incorporation of $\left[{ }^{3} \mathrm{H}\right]$ leucine with increasing incubation time into the proteins of all isolated subcellular fractions (Figs. 6 and 7). The microsomal fraction exhibited the highest specific radioactivity, followed in turn by the mitochondrial, nuclear and soluble fractions.

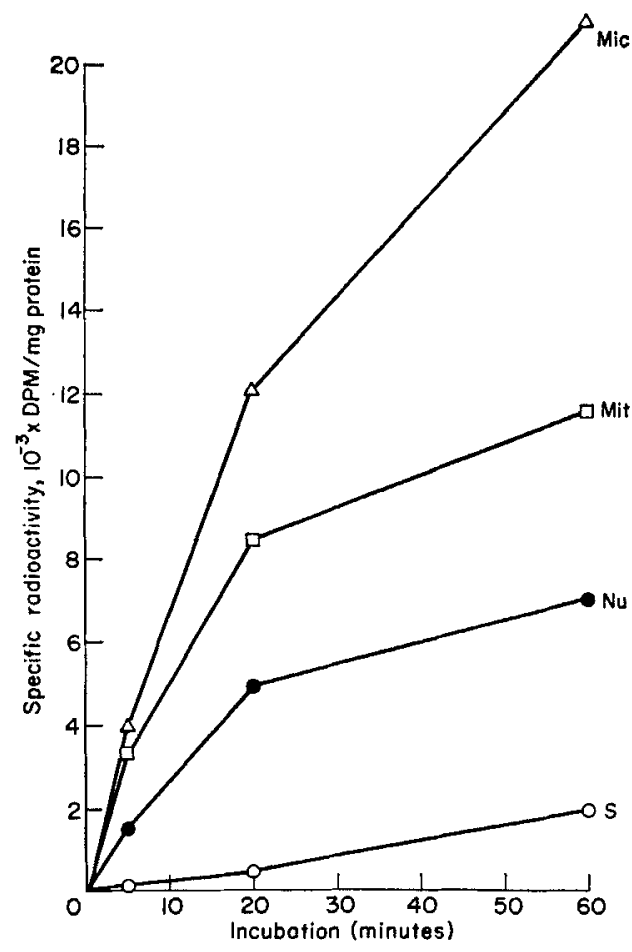

FIG. 7.-The data in Fig. 6 have been replotted as specific radioactivity (d.p.m. per mg of protein). For explanation of abbreviations, see legend for Fig. 6.

\section{DISCUSSION}

Protein synthesis as measured in the neuronal perikarya isolated by the procedure of SELLINGER et al. (1971a) is strongly influenced by the ionic composition of the incubating medium (Fig. 4) and is inhibited both by metabolic inhibitors and those acting specifically on protein synthesis (Table 2 ). The requirements of the synthetic system for $\mathrm{Mg}^{2+}$ and GTP (Table 1) as well as the marked inhibitions obtained using puromycin, cycloheximide and RNase (Table 2) show that the incorporation of $\left[{ }^{3} \mathrm{H}\right]$ leucine into protein refiects a true ribosome-dependent synthesis. It is thus clearly distinct from the recently noted aminoacyl-tRNA-protein transferase reaction in 
which amino acids are transferred from the aminoacyl-tRNA directly onto the aminoterminal residue of a pre-existing protein acceptor (SOFFER, HORINISHI and LIEBowITZ, 1969; SOFFER, 1970) and which shows no requirement for ribosomes, $\mathrm{Mg}^{2+}$, GTP and template nucleic acids. Our neuronal protein-synthesizing system also differs from the ribosome-independent amino-acid-incorporating system discovered by RAO and TARVER (1970) in the lipid-rich supernatant fraction of rat liver and which was also insensitive to puromycin and RNase.

The system described in this study synthesized both soluble and particulate protein (Table 3 ) and the protein-bound radioactivity increased with increasing incubation time in all subcellular fractions (Fig. 6). Similar responses were reported by BLOMSTRAND and HAMBERGER (1970) for a neuron-enriched fraction prepared from rabbit brain cortex slices. After $30 \mathrm{~min}$ of incubation, they reported a specific radioactivity of 3500 c.p.m. per $\mathrm{mg}$ of protein. On the other hand, TIPLADY and RosE (1971) reported a specific radioactivity of 1660 d.p.m. per $\mathrm{mg}$ of protein with the use of $\left[{ }^{3} \mathrm{H}\right]$ lysine. The latter workers did not specify whether they subjected the acidprecipitated radioactive material to heating at $90^{\circ} \mathrm{C}$ to eliminate the contribution of radioactive aminoacyl-tRNA, nor did they report any effects of inhibitors. In our experience reductions of up to 70 per cent of the total d.p.m. were noted after heating in $10 \%(\mathrm{w} / \mathrm{v}) \mathrm{TCA}$ at $90^{\circ} \mathrm{C}$ for $30 \mathrm{~min}$ when using an unfortified incubation medium (medium $B_{1}$, see Methods) similar to that used by TIPLADY and Rose (1971). The actual molar incorporation of $\left[{ }^{3} \mathrm{H}\right]$ leucine into protein is difficult to calculate since exact knowledge of the variations in specific radioactivity of leucine during incubation is lacking and because the 'true' specific radioactivity of the leucine pool is not necessarily that of the sum of the added and of the endogenous leucine at the beginning of the incubation. In fact, JoNES and McILWAIN (1970) noted significant increases of the levels of free amino acids as a result of protein breakdown during incubation of brain slices, and HANKING and ROBERTs (1965) observed similar effects when using liver slices. For these reasons, although the present system appears to be as active as the system of the Swedish group (BlOMSTRAND and HAMBERGER, 1970; BlomSTRAND et al., 1971) and, possibly, more active than that of TIPLADY and ROSE (1971), direct quantitative comparison of its performance with that of any other system is not strictly valid.

In separate experiments, we noted that the formation of the heat-resistant, TCA-precipitable, radioactive material in the unfortified medium A (see Methods and Table 1) was insensitive to puromycin and cycloheximide. Further tests (KoHL and SELlinger, manuscript in preparation) indicate that this basal level of incorporation probably represents a ribosome-independent synthetic response similar to that described by SOFFER et al. (1969) and SOFFER (1970). Using medium C (see Methods) we recovered a constant proportion (about 42 per cent) of the radioactive protein formed at any time during the incubation in soluble (non-sedimentable) form (Table 3). These results imply that the neuronal polyribosomes (JOHNSON and SELLINGER, 1971) maintain unimpaired their capacity to release nascent polypeptides and, moreover, are in accord with previous findings; namely, that the neuron from 8-day-old brain synthesizes 'exportable' soluble proteins at a more rapid rate than its mature counterpart (Sellinger et al., 1971a). Using a suspension of brain tissue, TIPLADY and Rose (1971) reported 8 per cent of the incorporated radioactivity as soluble protein, whereas in the neuronal system of BLOMSTRAND et al. (1971) the highest specific radioactivity 
was that of the proteins recovered in the high-speed soluble supernatant. The specific radioactivity of the soluble proteins formed in the present system was only about 11 per cent of that of the particulate proteins (Table 3), a rather low estimate attributable principally to the presence of some residual bovine serum albumin in the nonsedimentable fraction of the neuronal perikarya (Sellinger and Santiago, unpublished observations).

The addition of selected individual amino acids depressed the incorporation of $\left[{ }^{3} \mathrm{H}\right]$ leucine into protein (Fig. 5). Differential effects were seen, since L-methionine was a more effective inhibitor than $\mathcal{L}$-tryptophan, D-methionine or $\alpha$-methyl-DLmethionine. The extent of inhibition also increased with increasing concentration of the amino acid. Figure 5 also shows that the inhibitory effect produced by a given concentration of L-methionine was greater when an energy-generating system was supplied than in its absence (compare curves in media $\mathbf{B}_{1}$ and $\mathbf{C}$ ), a finding suggesting that the inhibition does not result from the trapping of ATP to form $S$-adenosylmethionine, with consequent depletion of the cellular high-energy phosphate, but rather that it represents a direct interference with the mechanisms of synthesis. In related studies on a homogenate of rat brain, PETERSON and MCKEAN (1969) observed that phenylalanine inhibits the incorporation of tyrosine and that isoleucine inhibits the incorporation of leucine. FolbERGRova (1966) reported an inhibition of the incorporation of $\left[{ }^{14} \mathrm{C}\right]$ lysine, valine and leucine and of $\left[{ }^{35} \mathrm{~S}\right]$ methionine into the proteins of cerebral cortical slices by various mixtures of non-radioactive amino acids, and ZOMZELY et al. (1964) showed a similar inhibition of the incorporation of leucine into cerebral microsomal and ribosomal proteins. More recently, TIPLADY and Rose (1971) reported $30-40$ per cent inhibition of the incorporation of $\left[{ }^{3} \mathrm{H}\right]$ lysine into neuronal protein by a mixture of non-radioactive amino acids and APPEL (1970) showed that the addition of mixtures of amino acids or of an excess of a specific amino acid inhibits the accumulation of radioactive amino acids by brain slices, with consequent inhibition of protein synthesis. APPEL (1970) also suggested that amino acid activation, prior to reaction with a specific transfer RNA, may be inhibited in the presence of other amino acids.

The incorporation of $\left[{ }^{3} \mathrm{H}\right]$ leucine into neuronal protein was stimulated by $\mathrm{K}^{+}$, while $\mathrm{Na}^{+}$was inhibitory (Fig. 4). This selective effect of $\mathrm{K}^{+}$was not seen by Blomstrand and HAMBERGER (1970), who noted a moderate stimulation of protein synthesis by both $\mathrm{K}^{+}$and $\mathrm{Na}^{+}$, the latter probably attributable to a requirement by the leucine transport system for $\mathrm{Na}^{+}$. APPEL et al. (1969) also reported that $\mathrm{Na}^{+}$ enhances the affinity of leucine for components mediating its transport across the synaptosomal membrane and that $\mathrm{K}^{+}$inhibits the uptake of leucine by the synaptosomes. The incorporation of $\left[{ }^{14} \mathrm{C}\right]$ leucine into the proteins of isolated glial cells was recently studied by TAKAHASHI et al. (1970), who noted a significant reduction of this process in the presence of $105 \mathrm{mM}-\mathrm{K}^{+}$. Elevation of the concentration of $\mathrm{K}^{+}$in the medium also depressed protein synthesis in brain slices (JoNEs and MCILWAIN, 1970). Inhibitory effects of $\mathrm{K}^{+}$on protein synthesis in brain in vitro apparently occur in systems having relatively intact membrane structures, whereas in systems devoid of intact membranes, $\mathrm{K}^{+}$stimulates protein synthesis by direct interaction with ribosomal sites (BoNDY and PerRY, 1963; Zomzely et al., 1964).

Figures 6 and 7 illustrate the increasing incorporation with incubation time into the proteins of the neuronal subcellular fractions, with the microsomal fraction 
exhibiting the highest specific radioactivity at all times. JOHNSON and SELLINGER (1971) also reported the specific radioactivity of the microsomal fraction of isolated neuronal perikarya to be highest at $10 \mathrm{~min}$ after a pulse of intrathecally-injected $\left[{ }^{14} \mathrm{C}\right]$ phenylalanine. The soluble cell sap fraction (Fig. 7) had the lowest specific radioactivity (for reasons already discussed), and never exceeded 10 per cent of that of the microsomal fraction, whereas the nuclear and mitochondrial fractions acquired sizable proportions of the total radioactivity (Fig. 6) and became rather markedly labelled (Fig. 7). Thus our results demonstrate labelling of the proteins in all of the subcellular compartments of the neuronal perikaryon and point to the ribosomes as the apparent major sites of protein synthesis in the nerve cell. We do not rule out, however, the contributions of other cellular sites of synthesis, such as the mitochondria (HALDAR, 1970) and the nuclei (BURDMAN, 1970) or of a system of specific amino acyl-tRNA protein transferases (SOFFER, 1970).

Acknowledgements-We thank Mr. W. G. OHLsson and Mrs. Josephine C. SANTIAgo for their expert technical assistance. The competent assistance in electron microscopy of Mrs. Patricia D. Petiet]is gratefully acknowledged.

\section{REFERENCES}

Acs G., Neidle A. and Schineiderman N. (1962) Biochim. biophys. Acta 56, 373.

Apped S. H. (1970) In Protein Metabolism of the Nervous System (Edited by LaJTHA A.) p. 621. Plenum Press, New York.

Appel S. H., Autilio L., Festoff B. W. and Escueta A. V. (1969) J. biol. Chem. 244, 3166.

Blomstrand C. (1971) Studies on Protein Metabolism in Neuronal and Glial Cell-Enriched Fractions from Brain Tissue. Ph.D. Thesis, Univ. of Göteborg, Göteborg, Sweden.

Blomstrand C. and Hamberger A. (1969) J. Neurochem. 16, 401.

Blomstrand C. and Hamberger A. (1970) J. Neurochem. 17, 1187.

Blomstrand C., Hamberger A. and Yanagihara T. (1971) J. Neurochem. 18, 1469.

Bondy S. C. and PerRy S. V. (1963) J. Neurochem. 10, 603.

Burdman J. A. (1970) J. Neurochem. 17, 1555.

Burdman J. A. and Journey L. J. (1969) J. Neurochem. 16, 493.

Campbell M. K., Mahler H. R., Moore W. J. and Tewari S. (1966) Biochemistry, Easton 5, 1174.

Cotman C. W., Herschman H. and Flansburgh D. (1970) Trans. Am. Soc. Neurochem. $1,35$.

Croft D. N. and Luban M. (1965) Biochem. J. 95, 612.

Fleischer-Lambropoulos H. and Reinsch I. (1971) Hoppe-Seyler's Z. physiol. Chem. 352, 593.

Folbergrová J. (1966) J. Neurochem. 13, 553.

GoldBerg M. A. (1971) Brain Res. 27, 319.

Goodwin F., Shafritz D. and WeissBach H. (1969) Archs Biochem. Biophys. 130, 183.

Hatdar D. (1970) Biochem. biophys. Res. Commun. 40, 129.

HANking B. M. and Roberts S. (1965) Biochim. biophys. Acta 104, 427.

Hemminki K., Huttunen M. O. and JARnefelt J. (1970) Brain Res, 23, 23.

Johnson D. E. and Sellinger O. Z. (1971) J. Neurochem. 18, 1445.

JoHnSon T. C. (1968) J. Neurochem. 15, 1189.

Johnson T. C. and LutTGes M. W. (1966) J. Neurochem. 13, 545.

Johnston P. V. and Roots B. I. (1970) Int. Rev. Cytol. 29, 265.

Jones D. A. and MCIlwain H. (1971) J. Neurochem. 18, 41.

Kohl H. and Sellinger O. Z. (1971) Fedn Proc. Fedn Am. Socs exp. Biol. 30, 1139 abs.

LeRner M. P. and Johnson T. C. (1970) J. biol. Chem. 245, 1388.

LIM L. and ADAMS D. H. (1967) Biochem. J. 104, 229.

LøVTR UP-ReIN H. (1970) Brain Res. 19, 433.

Lowry O. H., Rosebrough W. J., Farr A. L. and Randall R. J. (1951) J. biol. Chem. $193,265$.

MAhler H. R., Jones L. R. and Moore W. J. (1971) Biochem. biophys. Res. Commun. 42, 384.

Murthy M. R. V. and RAPPOPORT D. A. (1965) Biochim. biophys. Acta 95, 121.

Obrig T. G., Culp W. J., McKeehan W. J. and Hardesty B. (1971) J. biol. Chem. $246,174$.

Oja S. S. (1967) Annls. Acad. Sci. fenn., Series A, No. 131.

Peterson N. A. and McKean C. M. (1969) J. Neurochem. 16, 1211.

Rao K. R. and TARver H. (1970) Archs Biochem. Biophys. 141, 758. 
Sellinger O. Z., Azcurra J. M., Johnson D. E., Ohlsson W. G. and Lodin Z. (1971a) Nature New Biol, Lond. $230,253$.

Sellinger O. Z., Medzihradsky F., Santiago J. C. and Nandhasri P. (1971c) J. Cell Biol., Abstr., 11 th Ann. Meeting, New Orleans, La.

Sellinger O. Z. and Ohl.sson W. G. (1969) Life Sci. 8, 1083.

Sellinger O. Z., Ohlsson W. G., Frankel A. J., Azcurra J. M. and Petiet P. D. (1971b) J. Neurochem. 18, 1246.

SOFFER R. L. (1970) J. biol. Chem. 245, 731.

SofFer R. L., Horinishi H. and Liebowitz M. L. (1969) Cold Spring Harb. Symp. quant. Biol. 34, 529.

Stenzel K. H., Aronson R. F. and Rubin A. L. (1966) Biochemistry, Easton 5, 930.

Takahashi Y., Hsu C. S. and Honma S. (1970) Brain Res. 23, 284.

Tiplady B. and Rose S. P. R. (1971) J. Neurochem. 18, 549.

VAhVelainen M. L. and OJA S. S. (1969) Brain Res, 13, 227.

Zomzely C. E., Roberts S., Gruber C. and Brown D. M. (1968) J. biol. Chem. 243, 5396.

Zomzely C. E., Roberts S., Peache S. and Brown D. M. (1971) J. biol. Chem. 246, 2097.

Zomzely C. E., Roberts S. and Rapaport D. (1964) J. Neurochem. 11, 567. 